PRAGATI: Journal of Indian Economy Volume 4, Issue 1, January-June 2017, pp. 1-22 doi:10.17492/pragati.v4i01.9544

\title{
Determinants of Sanitary Practices in Rural Odisha
}

\author{
Chittaranjan Nayak* and Prasanta Patri**
}

\begin{abstract}
Proper sanitation, hygiene and cleanliness are some of the key indicators of quality of life. The present paper attempts to study the status of sanitation in rural Odisha and explore its determinants. The paper is based on both primary as well as secondary data. The relative position of districts in rural sanitation is analysed with help of census data. The analysis observes that there is a significant regional divide in 'access to toilets' across the districts of Odisha. The backward districts are lying way below the relatively advanced coastal districts of the state. Moreover, for an investigation at a disaggregated level, we had taken 109 households from a village cluster for a case study. The study observes that caste category, occupation and government subsidy are the important factors influencing the sanitary practices of the study areas. The paper advocates for continuance of government subsidy with better targeting, and a massive awareness drive by the government to change the sordid state of open defecation in the state.
\end{abstract}

Keywords: Rural sanitation; Open defecation; Probit analysis.

\subsection{Introduction}

Proper sanitation, hygiene and cleanliness are the symbols of a civilised society. For health and socio-economic development sanitation is very crucial and must not be neglected. However, due to a number of reasons, a large mass of people especially in rural India and urban slums defecate in open. According to UNICEF, two third of India's population lives with unimproved sanitation and an estimated 564 million people defecate outside, representing 59 percent of the global population practicing open defecation. This leads to a lot of health issues. Children suffer from hook worm and round worm infection which lead to stunted growth.

\footnotetext{
* Corresponding author; Assistant Professor of Economics, Ravenshaw University, Cuttack, Odisha, India. (Email id: chittaranjan.ru@gmail.com)

**Research Assistant, Department of Humanities and Social Science, National Institute of Technology, Rourkela, Odisha, India. (Email id: patrisonu@gmail.com)
} 
Faecal pathogens enter into human body creating various health issues. Pregnant women face many problems which in turn increase maternal mortality and neo natal mortality. (http://unicef.in/Whatwedo/11/Eliminate-Open-Defecation). Sanitation and hygiene are important not only from public health point of view but also from the view point of socioeconomic development of individuals, because there is positive link between sanitation overheads and economic development and without proper sanitation morbidity rate increases, which hampers productivity of labour. Consequently, good sanitation on its own merits can be considered as an important indicator of development. People living in developed countries have access to a private flush toilet with continuous supply of piped water with taps in close proximity. On the other hand, in many developing and underdeveloped countries, sanitation is considered as a luxury. Millions of people defecate in open- road sides, agricultural fields, railway tracks, etc.- contributing to a number of health issues. Diarrhoea, which is most often related to unsafe drinking water, poor sanitation and inadequate hygiene, is one of the leading causes of death among children under the age of five. It kills more children than Malaria or HIV/AIDS do. WHO (2012) estimates that the exposure to inadequate drinking water, sanitation and hand hygiene was responsible for 58 percent of deaths from diarrhoea, adding up to 8,40,000 deaths in low and middle-income countries.

India is far behind many other countries in sanitation Index. The country has performed abysmally low by occupying the $93^{\text {rd }}$ position in the global index on water and sanitation. Even countries like Zimbabwe, Pakistan and Bangladesh are above India in this crucial social index. But the story is not uniform across the Indian states. On the other hand, some provinces likes Kerala, Manipur, Himachal Pradesh and Mizoram have very high rates of access to toilets, i.e. above 80 percent, in some other states like Jharkhand, Odisha and Bihar the access is very low.

This paper considers the case of Odisha because it is a representative of low performing states in rural sanitation. This necessitates an in-depth analysis to examine the sanitary situation across the districts, identify the determinants and understand their relative effectiveness in determining the sanitary performance in the state. In spite of many governmental schemes ${ }^{1}$ implemented in the country on sanitation, it seems that the benefits of such schemes have not percolated to the common households in Odisha. According to Swachhta Status Report 2016, the percentage coverage of toilet in rural Odisha was just $18.7 \%$ in 2012 as against 97.2\% in Kerala (NSSO 2016, 31). Women and girls often wait all the day for defecation until it is dark increasing their chances of infection and exposing them to teasing of onlookers or even snake bites as they go out to remote spots. Given this backdrop, it becomes imperative to scrutinize 
whether or not governmental intervention has any role in determining toilet owning status. Needless to state that government intervention through subsidy also requires a 'critical minimum level' of awareness and a threshold income, in the absence of which those interventions may not yield the desired outcome. It is startling that despite its considerable importance, the issue has not invited proper attention of researchers in India, particularly in Odisha context.

The present paper aims at examining the status of sanitation in rural Odisha and exploring the socio-economic determinants of rural sanitation district wise, as well as in the primary study area. In addition to the present section, the study consists of four other sections. Section 2 presents a review of some available literature. Section 3 describes the methodology and database. Section 4 has presented the status of sanitation in rural Odisha, in which an attempt is made to show disparity across districts. An attempt is also made to identify the determinants of rural sanitation in Odisha. This chapter is basically based on secondary data. Section 5 examines the household determinants of toilet ownership. A Probit analysis is done with help of the primary data collected from the study area. Section 6 summarises the findings.

\subsection{Review of Literature}

A systematic review and meta-analysis by Fewtrell et.al. (2005) focused attention on how the neglect of sanitation and hygiene issues results in increased cases of diarrhoea all over the globe. The study suggests that hand washing with soap can reduce respiratory infections in children under five by 50 percent. Hand washing interrupts the transmission of disease agents and so can significantly reduce diarrhoea and respiratory infections, as well as skin infections and trachoma. Banda, Sarkar, et.al, 2007 in their article have studied the socio-cultural factors impacting on water safety and practices of water handling, sanitation and defecation in rural Tamil Nadu across social categories. Their survey shows that hand washing with soap after defecation varied widely with age i.e. more children are using soap after defecation and before meals as compared with people above the age of 60 years.

On the basis of a cross-sectional study, Coffey et al. (2014) assess that despite economic growth, government latrine construction and increasing recognition among policy makers, open defecation remains widespread in rural India. They show that people have a revealed preference for open defecation because of various reasons. This kills hundreds and thousands of babies and stunts growth of children. Patil, Salvatore and Ganguly (2014) carried out a study on defecation behavior and child health in 80 rural villages in Madhya Pradesh. The study showed that there is a modest reduction in 
4 | PRAGATI: Journal of Indian Economy, Volume 4, Issue 1, January-June 2017

open defecation but it is insufficient for child health outcome (diarrhoea, parasite infection anemia, growth).The result showed the difficulty in achieving adequate improvement in sanitation levels to deliver expected health benefits.

Kumar and Das (2014) made a study on drinking water and sanitation facility in India and its linkages with diarrhoea among children under five. By using data from Census of India, 1981-2011 and the third round of National Family Health Survey (NFHS-3, 2005-06) as stated in Arnold, Parsuraman, et al. (2009) and the method of binary logistic regression technique, the findings of the study showed that households with unimproved latrine facility were having a higher chance of having diarrhoea among children under five.

A religion-wise latrine demand is understood by a recent working paper by Geruso and Spears (2015). On the basis of NFHS data of 1992/93, 1998/99 and 2005/06, they observed that there is significant difference between household toilet demand between Muslim and Hindu families. In their study it is observed that there is a causal relationship between high infant mortality rate and open defecation, for example in India IMR is high so is the rate of open defecation. Infant mortality is 17 percent higher for Hindus than Muslims, because the prevalence of open defecation is particularly high among Hindu families.

As regards Odisha, Bernard et.al (2013) made a study on impact of Total Sanitation Campaign (TSC) on latrine coverage and use in the state. They have conducted a cross sectional study to investigate latrine coverage and use among 20 villages (447 households, 1933 individuals) in Odisha, where TSC campaign had been implemented before three years. They have used a bivariate analysis and a chi-square test to conduct outcome variables and found that mean latrine coverage of the villages was 72 percent compared to less than 10 percent in comparable villages in the same district where TSC had not yet been implemented. The study also reveals that more than a third (39 percent) of the toilets was not being used by any members of the household. The conclusion of the study shows that TSC has substantial gains in latrine coverage.

Clasen et.al. (2014) in their study have aimed at assessing the effectiveness of rural sanitation intervention by taking in to consideration India's Total Sanitation Campaign (TSC). Using a cluster randomised controlled trial for rural Odisha, they took randomly 50 villages to the intervention group and 50 villages to the controlled groups. The findings of their study show intervention has increased the mean village level latrine coverage, which is responsible for reducing exposure to faecal pathogens and related diseases. 
Although a few scholars have attempted the situation of sanitary status, there seems to be scanty attention on finding its determinants especially in a state which is considered as a straggler. The present paper is an attempt in this regard.

\subsection{Methodology and Data}

The present study is based on both primary and secondary data. The secondary data for this study is collected from different sources which include Census 2011 \& 2001, and Economic Surveys of India and Odisha for different years. First of all, an attempt is made to observe the position of Odisha among all the Indian states, and then we have analysed disparity in 'access to toilet' across the districts of Odisha. An attempt is also made to explore the determinants of sanitation with help of secondary data. The variables compiled from secondary data are as follows:

a) PHHT: Percentage of rural households having toilet. This is considered as a proxy variable of 'access to toilet', an indicator of rural sanitation- the dependent variable in this study. District-wise data on PHHT have been collected from Census 2011 \& 2001.

b) RLR: Rural Literacy Rate. This is defined as the percent of rural population literate. Data on RLR are also taken from Census 2011. RLR may be considered as a surrogate of public awareness in rural areas. Higher RLR is expected to cause higher PHHT.

c) PNDP: Per capita Net District Domestic Product. For this, NDDP of 2010-11 at 200405 prices has been divided by the total population of the district for the same year. Thus PNDP comprises both rural as well as urban income. In the absence of ruralurban disaggregated data, this variable is considered as a measure of capability of people to have a toilet at.

d) RD: Regional Dummy. Odisha is regionally divided between the coastal (northeastern and south-eastern coast) and western (north-western and south-western) regions. The latter is considered as poorer. In the western part $\mathrm{KBK}^{2}$ region is considered as the most backward region. In addition to the eight KBK districts, the present study has considered three other districts viz. Sambalpur, Debagarh and Gajapati on the basis of Integrated Action Plan (IAP) classification of the Government of India. The present study has considered these eleven IAP districts as the benchmark. Therefore, $\mathrm{RD}=1$, if a district is an IAP district; 0 , otherwise. It is expected to negatively determine PHHT because a backward district is likely to have lower sanitary status. 
6 | PRAGATI: Journal of Indian Economy, Volume 4, Issue 1, January-June 2017

One way ANOVA technique is used to study the disparity across the 30 districts of the state. Post Hoc analysis is used for difference count between the Top Ten, Medium Ten and the Bottom Ten districts. An attempt is also made to analyse the difference between the IAP and non-IAP districts. Linear regression model is used for the analysis of secondary data.

Model: PHHT $_{i}=\beta_{0}+\beta_{1} R_{L R}+\beta_{2}$ PNDP $_{i}+\beta_{3} R_{i}+\epsilon_{i}$, where $\epsilon_{i}$ is the error term, $\mathrm{i}=1,2,3 \ldots ., 30$ districts of Odisha.

Considering the inadequacy of the secondary data, an attempt is also made to understand the problem through a micro level study. Primary data have been collected from 109 households from the Ochinda village cluster of Jajpur district by using questionnaire-cum-schedule method.

\subsection{Profile of the study area}

Ochinda is a medium size village in the Panikoili gram panchayat of Korei block in Jajapur district of Odisha. This village and three other neighbouring villages viz. Khasagadia, Tajpur and Mulari which are located within 1 kilometer radius of Ochinda have been selected for the study purposively. The village cluster is located around 32 KM towards west from the district Head Quarters Jajpur and $101 \mathrm{KM}$ from the State capital Bhubaneswar. Although all these are revenue villages as per census record, they possess similar socio-economic and geographical conditions. As per Census 2011, there are 88 households in Khasagadia, 139 in Tajpur, 101 households in Ochinda and 101 households in Mulari village. All the households of the village cluster were pooled together and divided into social categories as General, OBC and SC. An attempt was made to select around 35 families from each category with equal representation of families with and without toilets on the basis of 'stratified random sampling with fixed allocation' method. However, due to non-availability of adequate families especially in 'household having toilet' category in OBC and SC groups, adjustment has been made with the final number. A total of 109 households have been surveyed. The variables of the primary data analysis are detailed in Table 1.

The occupation categories in the village mainly include farmers, agricultural labourers, non-farm people including both employers as well as workers, and a few service holders. It is observed that some of the farm-workers also work in steel industries like in Vedanta and Tata Steel located in nearby Jajpur Road during offseasons. A structured questionnaire-cum-schedule was used for primary data collection. On the basis of primary data, the study has analysed the toilet owning status of households vis-à-vis education, occupation, income and government subsidy. Chi-square test has been used to examine independence of the characteristics. After scrutinizing a 
good number of possible regressors like percentage of female members in the household, number of adult members in the household, schooling of the head of the household, schooling of the female members of the household, per capita income and so on, a few right hand side variables are shortlisted on the basis of backward regression and theoretical underpinning. In order to study the determinants of sanitary practices of rural Odisha, toilet ownership is taken as a binary variable. The Probit model ${ }^{3}$ is chosen as the appropriate model considering its advantages over other models.

Table 1: Socio-Economic Variables in the Primary Survey

\begin{tabular}{|c|c|c|c|}
\hline Domain & $\begin{array}{l}\text { Variable } \\
\text { label }\end{array}$ & Definition & Expected Impact \\
\hline Social & $\begin{array}{l}\mathrm{SC} \\
\mathrm{OBC} \\
\mathrm{GEN}\end{array}$ & $\begin{array}{l}\text { Official definition of different categories } \\
\text { is taken. In the model two dummy } \\
\text { variables are taken for SC and OBC } \\
\text { categories }\end{array}$ & $\begin{array}{ll}\text { Backwardness } & \text { in } \\
\text { caste may lead } & \text { to } \\
\text { some sort } & \text { of } \\
\text { deprivation } & \text { in } \\
\text { access to toilet. } & \end{array}$ \\
\hline \multirow[t]{2}{*}{ Economic } & MPCI & $\begin{array}{l}\text { Monthly per capita Household Income. } \\
\text { This is further categorised as Chronically } \\
\text { poor, Poor, Above average, and Relatively } \\
\text { richer }\end{array}$ & \multirow[t]{2}{*}{$\begin{array}{l}\text { Both these are } \\
\text { expected to have } \\
\text { positive impact }\end{array}$} \\
\hline & SUB & $\begin{array}{l}\text { Subsidy for toilet (dummy). 1-Yes, 0- } \\
\text { otherwise }\end{array}$ & \\
\hline Occupational & OCCU & $\begin{array}{l}\text { Categorised as 1.Farm workers including } \\
\text { both farmers and labourers, } 2 \text {. Low paid } \\
\text { non-farm workers, 3.High paid non-farm, } \\
\text { basically the employers, } 4 \text {.Service holders. } \\
\text { The occupation which contributes the } \\
\text { highest proportion of earning to the family } \\
\text { income is considered as the occupation of } \\
\text { the household. All the four categories are } \\
\text { pooled and sub-divided into binary } \\
\text { categories as High Earning(1), and Low } \\
\text { Earning occupations }(0) \text {, as a dummy OD. }\end{array}$ & $\begin{array}{l}\text { The division in } \\
\text { ascending order is } \\
\text { expected to have } \\
\text { positive impact on } \\
\text { toilet owning }\end{array}$ \\
\hline Educational & $\mathrm{AE}$ & $\begin{array}{l}\text { Average years of schooling of adult } \\
\text { (above } 15 \text { years) members of households. } \\
\text { This is further categorised into two: below } \\
5 \text { years (i.e. the median year of schooling), } \\
\text { and above } 5 \text { years of schooling. EDUD=1, } \\
\text { if AE is below } 5 \text { years, } 0 \text {-otherwise }\end{array}$ & $\begin{array}{l}\text { Expected to have } \\
\text { positive impact on } \\
\text { sanitation. }\end{array}$ \\
\hline
\end{tabular}


8 | PRAGATI: Journal of Indian Economy, Volume 4, Issue 1, January-June 2017

It may be noted here that Jenkins (2009) has taken Monthly Per capita Income (MPCI) of the households as a determinant. Jenkins (2009) has also taken occupation of head of the household as a regressor. While the present paper takes MPCI as a regressor, it considers occupations of all the adult members of the household to find its major occupation. Barnardet et al. (2013) have taken AE and Caste as regressors for sanitation. The present study has converted AE to a dummy on the basis of percentile division. Other variables of education like average female education, education of the head of the household were also considered but $\mathrm{AE}$ is chosen finally on the basis of regression through backward elimination. Subsidy is considered as a determinant by Sriram (2013). The present study also considers the same.

\subsection{Results and Discussion}

The overall performance of sanitation in India is quite dismal. However, the story of all the states cannot be considered as similar. This section intends to make a brief mention of rural sanitation across all the Indian states and with special focus on Odisha. Thereafter a similar attempt is made to assess disparity in rural sanitation of all the thirty districts on the basis of census 2011 housing and amenities data. Thereafter, relationship of rural sanitation with some selected socio-economic variables is examined with correlation and regression analysis. The results from the primary data analysis are presented subsequently.

\subsection{Status of sanitation in rural Odisha vis-à-vis other Indian states}

The present paper considers toilet as the proxy measure of rural sanitation. From a comparison of census data 2011 with 2001, it is found that almost all the BIMARU ${ }^{4}$ states are in the bottom level in 'access to rural sanitation'. Jharkhand, Madhya Pradesh and Odisha are the three worst performers. The position of Odisha in the toilet use is third from below. In 2011, only about 14 percent of rural households had owned a toilet, whereas it is about $93 \%$ in case of Kerala.

If we go for a region-wise analysis, the North-Eastern India which includes the seven sisters Assam, Manipur, Arunachal Pradesh, Mizoram, Nagaland, Meghalaya and Tripura, and Sikkim are probably the best performers among all the Indian states. In fact Manipur, Mizoram, Sikkim and Tripura are in the top five states after Kerala. Certainly, this points out that merely economic growth is not sufficient for better social indicator. Otherwise, the north-eastern states are not economically superior yet they are the best performers in rural sanitation. Reinforcing this argument, we observe that the states like Karnataka and Tamil Nadu which are considered as relatively superior both in literacy 
and per capita income are in the bottom ten states in 'access to rural sanitation'. Both these states have not even 30 percent of rural households owning a toilet.

Among the north Indian states, Haryana, Himachal Pradesh and Punjab are placed in the top ten category, whereas Uttar Pradesh are positioned in the bottom ten. In the western Indian states, Goa is among the top ten of India whereas Rajasthan is in the bottom ten. Gujarat is just closer to the All India average of 31 percent. The position of Maharashtra is a little bit higher than the national average.

If the decadal growth rate is considered, then phenomenal growth is there in case of Himachal Pradesh. From less than 30 percent in 2001, household owning toilet in Himachal Pradesh has increased to about 70 percent in 2011. Similarly, the decadal differential is about 30 percent for Punjab, 25 percent for Haryana and Sikkim, 20 percent for Goa, West Bengal, Uttarakhand and Maharashtra. Jammu \& Kashmir alone shows a decline in percentage of households with toilets, implying that toilet construction could not keep pace with rural population growth. What is ironic is that the BIMARU states and Odisha which are lagging far behind are also showing the lowest growth differential in PHHT during the last decade. These states are considered as the laggards. A state like Assam which is comparable with Odisha in many socio-economic indicators is way ahead of the latter in rural sanitation. Therefore, the low performance of Odisha is a serious issue which needs further scrutiny.

\subsection{Performance of districts in rural sanitation}

All the thirty districts of the state are divided into three broad groups such as the top ten, the medium ten and the bottom ten districts on the basis of percentage of rural households having toilets. The categorization of districts is presented in Table 2. Clearly these three categories show a regional divide of toilet owning status.

The 'top ten' category mainly consists of the coastal districts, whereas the KBK districts are positioned in the 'bottom ten' category. The top five districts viz. Baleswar, Cuttack, Jagatsinghpur, Jajpur and Ganjam all are coastal districts. Puri is the only coastal district which is in 'middle ten' but at the top in that category. Central Odishan districts Nayagarh and Augul are, however, in top ten category. Nabarangapur, Debagarh, Malkangiri, Kandhamal and Rayagada are the worst performers. All of these districts are part of the most backward KBK region.

\subsection{Assessing disparity in sanitation}

The analysis makes a further enquiry of existence of disparity between the three categories of districts in relation to household toilet availability. One way ANOVA method is used for this purpose. The ANOVA results are stated in Table 3. The range of 
PHHT is the highest for the 'Top Ten' districts, and the lowest in case of the 'Bottom Ten' districts. The Levene statistics which tests homogeneity of variances of the groups is computed to be 4.398, with p-value 0.022. This means the variances are not homogeneous. The F-value is significant at $\mathrm{p}=0.000$. This indicates that there are significant differences in the variances of the groups. The null hypothesis of no regional disparity in 'access to toilet' is rejected.

Table 2: Rank of Districts in Access to Toilets

\begin{tabular}{|c|c|c|c|c|c|}
\hline \multicolumn{2}{|c|}{ The top ten } & \multicolumn{2}{c|}{ The medium ten } & \multicolumn{2}{c|}{ The bottom ten } \\
\hline Districts & PHHT & Districts & PHHT & Districts & PHHT \\
\hline Baleswar & 22.72 & Puri & 15.62 & Sambalpur & 8.56 \\
\hline Cuttack & 22.37 & Mayurbhanj & 15.03 & Sundargarh & 8.37 \\
\hline Jagatsinghpur & 22.11 & Dhenkanal & 14.21 & Kalahandi & 8.24 \\
\hline Jajpur & 19.89 & Nuapada & 12.73 & Koraput & 8.18 \\
\hline Ganjam & 19.07 & Gajapati & 12.65 & Subarnapur & 7.87 \\
\hline Khurda & 18.30 & Bargarh & 12.32 & Rayagada & 6.63 \\
\hline Anugul & 16.74 & Balangir & 10.11 & Kandhmal & 6.28 \\
\hline Bhadrak & 16.03 & Jharsuguda & 9.39 & Malkangiri & 5.96 \\
\hline Nayagarh & 15.90 & Kendujhar & 9.30 & Debagarh & 5.94 \\
\hline Kendrapada & 15.79 & Boudha & 8.99 & Nabarangpur & 5.82 \\
\hline
\end{tabular}

Source: Compiled from Census 2011

Table 3: ANOVA results for PHHT

\begin{tabular}{|c|c|c|c|l|c|}
\hline & Sum of Squares & df & Mean Square & F & Sig. \\
\hline Between Groups & 692.002 & 2 & 346.001 & 68.313 & .000 \\
\hline Within Groups & 136.753 & 27 & 5.065 & & \\
\hline Total & 828.755 & 29 & & & \\
\hline
\end{tabular}

Source: Computed by SPSS from census data

The significance of the differences between two out of the three groups taken separately is understood with the help of Post Hoc test. The results are presented in 
Table 4. The bottom, medium and the top categories are labelled as 0,1 and 2 respectively. The mean difference between each and every pair is found highly significant.

Table 4: Post Hoc Tests- Multiple Comparisons

\begin{tabular}{|r|r|r|r|r|r|r|}
\hline $\begin{array}{r}\text { (I) } \\
\text { PHHT }\end{array}$ & $\begin{array}{r}(\mathbf{J}) \\
\text { PHHT }\end{array}$ & $\begin{array}{r}\text { Mean } \\
\text { Difference (I-J) }\end{array}$ & $\begin{array}{r}\text { Std. } \\
\text { Error }\end{array}$ & Sig. & \multicolumn{2}{|r|}{$\mathbf{9 5 \%} \begin{array}{r}\text { Confidence } \\
\text { Interval }\end{array}$} \\
\cline { 5 - 7 } & & & & & $\begin{array}{r}\text { Lower } \\
\text { Bound }\end{array}$ & $\begin{array}{r}\text { Upper } \\
\text { Bound }\end{array}$ \\
\hline \multirow{2}{*}{0} & 1 & $-4.8502101^{*}$ & 1.0064726 & .000 & -6.91532 & -2.785099 \\
\cline { 2 - 7 } & 2 & $-11.7071755^{*}$ & 1.0064726 & .000 & -13.7722 & -9.642064 \\
\hline \multirow{2}{*}{1} & 0 & $4.8502101^{*}$ & 1.0064726 & .000 & 2.785099 & 6.915321 \\
\cline { 2 - 7 } & 2 & $-6.8569654^{*}$ & 1.0064726 & .000 & -8.92207 & -4.791854 \\
\hline 2 & 0 & $11.7071755^{*}$ & 1.0064726 & .000 & 9.642064 & 13.772287 \\
\cline { 2 - 7 } & 1 & $6.8569654^{*}$ & 1.0064726 & .000 & 4.791854 & 8.922077 \\
\hline
\end{tabular}

* The mean difference is significant at the 0.05 level.

Source: Census 2011

An attempt is also made to understand the disparity between the Integrated Action Plan (IAP) districts and the non-IAP districts in PHHT. There are eleven IAP districts in the state of Odisha. The IAP districts include all the KBK districts and some otherwise identified backward districts like Sambalpur, Debagarh and Gajapati. All the districts are placed either in IAP or in non-IAP category. The descriptive statistics and one way ANOVA results are presented in Tables 5 and 6 respectively. The Levene statistic is computed as 4.78 whose actual level of significance is 0.037 . This suggests that the variances of both the groups are not homogeneous. The ANOVA results indicate that there is significant difference in the variation between the IAP and non-IAP districts. The coefficient of variation for all the thirty districts is 0.43 .

Table 5: Descriptive Statistics of PHHT

\begin{tabular}{|r|c|c|c|c|c|c|c|}
\hline & \multirow{2}{*}{$\mathbf{N}$} & Mean & Std. Error & \multicolumn{2}{|c|}{ 95\% C.I. for Mean } & \multirow{2}{*}{ Min } & \multirow{2}{*}{ Max } \\
\cline { 5 - 7 } & & & & Lower Bound & Upper Bound & & \\
\hline IAP Districts & 11 & 8.42528 & .75018 & 6.7537 & 10.0967 & 5.8155 & 12.7257 \\
\hline Non-IAP district & 19 & 15.1796 & 1.1458 & 12.7723 & 17.5869 & 6.2774 & 22.7166 \\
\hline Total & 30 & 12.703 & .97601 & 10.7068 & 14.6991 & 5.8155 & 22.7166 \\
\hline
\end{tabular}


12 | PRAGATI: Journal of Indian Economy, Volume 4, Issue 1, January-June 2017

Table 6: ANOVA Results for PHHT- IAP and Non-IAP Category

\begin{tabular}{|r|r|r|r|r|r|}
\hline & Sum of Squares & df & Mean Square & F & Sig. \\
\hline Between Groups & 317.827 & 1 & 317.827 & 17.418 & .000 \\
\hline Within Groups & 510.927 & 28 & 18.247 & & \\
\hline Total & 828.755 & 29 & & & \\
\hline
\end{tabular}

\subsection{Regression analysis}

The study has considered three determinants of household access to toilets. These include rural literacy rate (RLR), per capita net district domestic product (PNDP), and a dummy variable to capture the impact of regional backwardness. Percentage of households having toilet (PHHT) is the dependent variable. The variables are selected on the basis of step-wise regression and a priori reasoning. The descriptive statistics of all the variables are presented in Table 7.

Table 7: Descriptive Statistics of the Variables

\begin{tabular}{|r|r|r|r|r|r|r|}
\hline Variable & Minimum & Maximum & Mean & $\begin{array}{r}\text { Std. } \\
\text { Deviation }\end{array}$ & Skewness & Kurtosis \\
\hline PHHT & 5.8155 & 22.7166 & 12.70304 & 5.3458 & .417 & -1.023 \\
\hline RLR & 35.0614 & 78.1791 & 59.91775 & 12.9822 & -.585 & -.752 \\
\hline PNDP & 14700 & 49021 & 23995.33 & 8006.072 & 1.540 & 2.315 \\
\hline
\end{tabular}

In the correlation matrix (not presented), only the correlation coefficient between PHHT and RLR is significant. It is positive as literacy and sanitation often move in the same direction. The results of the linear regression model is presented in Table 8. In Table 8 , it is observed that all the variables in the model have their expected signs. About 51 per cent variation in the dependent variable is explained by the regressors. Although all the regressors are found to be positive, only the coefficient with respect to RLR is found to be significant. This shows that the toilets owning status increases with increase in literacy status. Although the regression coefficient of the categorical variable $\mathrm{RD}$ is not significant, we attempted Mann-Whitney $\mathrm{U}$ Test for the null hypothesis that the distribution of PHHT is the same across category of regional dummy. The null was rejected. 
Table 8: Regression Coefficients

\begin{tabular}{|c|c|c|c|}
\hline Variable & $\boldsymbol{\beta}$ Coefficient & Standard Error & P-value \\
\hline Constant & -2.473 & 4.746 & .607 \\
\hline PNDP & $5.861 \mathrm{E}-005$ & .000 & .550 \\
\hline RLR & 0.2 & .080 & .019 \\
\hline RD & 2.78 & 2.196 & .217 \\
\hline
\end{tabular}

Dep. Variable: PHHT, The regional dummy $(R D)$ is 1 for non-IAP districts, O-otherwise.

$R^{2}=0.505$, Adj $R^{2}=0.447, N=30$

\subsection{Household determinants of toilet ownership}

The Millennium Development Goal (MDG) sets the target to reduce the proportion of the population without sustainable access to basic sanitation by fifty percent. The case of India, particularly for the states like Odisha, remains worrisome despite commendable efforts by some states. For a material understanding of the causes of pervasive open defecation needs further disaggregated data. The paper has, therefore, attempted a micro level evidence of a village cluster in Jajpur district of Odisha.

\subsubsection{Social category and toilet owning status}

Owing to its hierarchical superstructure, caste is considered as one of the best possible indicators of social status in India. Birth in a lower caste family confines educational attainment and income status of an individual. Apart from these, caste to a large extent decides occupation. Some occupations are considered as unclean which are socially imposed on the lower caste community. Hence, an obvious intuition is that the caste pyramid determines the access to toilet. The present analysis has gathered data from households belonging to three different caste categories such as General, OBC and SC. There was no family from the ST category in the village cluster. The cross tabulation of toilet owning status for different caste categories is presented in Table 9.

\section{Table 9: Caste and Toilet Owning Status}

\begin{tabular}{|c|c|c|c|c|}
\hline \multirow{2}{*}{$\begin{array}{c}\text { Toilet Owning Status } \\
\text { of Households }\end{array}$} & \multicolumn{3}{|c|}{ Category } & \multirow{2}{*}{ Total } \\
\cline { 2 - 4 } & GEN & OBC & SC & \\
\hline Not having toilet & 20 & 27 & 30 & 77 \\
\hline Having toilet & 20 & 8 & 4 & 32 \\
\hline Total & 40 & 35 & 34 & 109 \\
\hline
\end{tabular}

Source: Compiled from primary data 
The comparative picture is presented in the form of a bar diagram in Figure 3. The bar diagram explains the percentage of households owning toilet or not owning toilet within the caste categories.

\section{Figure 3: Caste Category and Toilet Owning Status}

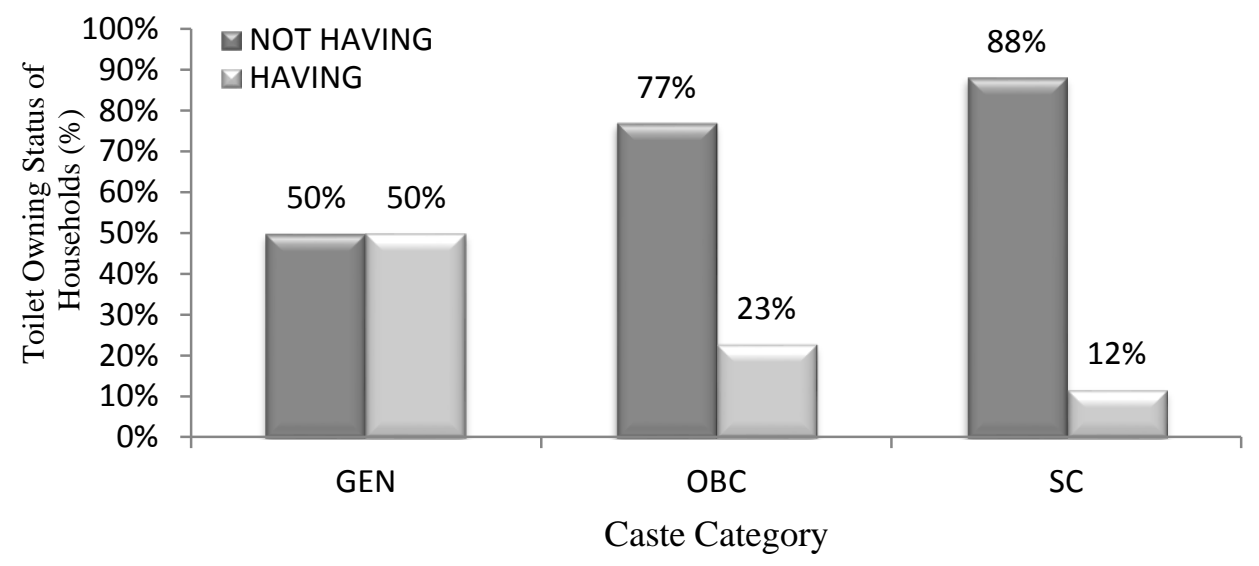

Source: Primary Data

As presented in Table 9, out of the 109 households, 40 households belong to General category (GEN), 35 belong to Other Backward Class (OBC) and 34 households belong to Schedule Caste (SC) households. From all these three categories 77 households (70.6\%) are not having toilets. Fig 3 makes the division clearer. Out of 40 GEN families 50 percent households are having toilets. But in case of OBC households, out of 35 families only 23 percent households are having toilets. The situation is worst for SC households. Only four out of thirty SC households, i.e. just about 13 percent own a toilet.

The question of whether or not toilet owning status is independent of caste of the households is examined by the Chi-square test (results of which are presented in a later section). The Chi-square statistic is computed as 14.001 and its exact level of significance (p-value) is 0.001 . The null hypothesis is rejected (Table 13). It is clear that the access to toilet is not independent of caste structure.

\subsubsection{Income category and toilet owning status}

Income is arguably one of the important determinants of sanitary status. Households are usually divided into BPL and APL families. The Rangarajan Committee (2012) estimates the rural poverty line on the basis of per day expenditure per individual 
which is Rs. 32. However, the present analysis observes that about 90 per cent of the total surveyed households are below this bench mark. Therefore, the paper takes an alternative division formula such as the percentile method of dividing households on the basis of monthly per capita income (MPCI). The median per capita monthly income of the households is found as Rs. 2500. The $25^{\text {th }}$ and $75^{\text {th }}$ percentiles are Rs. 1633.33 and Rs. 3875 respectively. Households are categorised into four relative groups as follows:

(i) Chronically poor: whose per capita family income is less than Rs. 1633.33.

(ii) Poor: whose per capita family income is in between Rs. 1633.33-Rs 2500.

(iii) Above average: whose per capita family income is in between Rs. 2500-Rs. 3875 .

(iv) Relatively richer: whose per capita family income is greater than Rs. 3875 .

Table 10: Income and Toilet Owning Status

\begin{tabular}{|l|c|c|c|c|c|}
\hline \multirow{2}{*}{$\begin{array}{c}\text { Toilet } \\
\text { Owning } \\
\text { Status }\end{array}$} & \multicolumn{4}{|c|}{ Income Categories of Households } & \multirow{2}{*}{ Total } \\
\cline { 2 - 5 } & $\begin{array}{c}\text { Chronically } \\
\text { poor }\end{array}$ & Poor & $\begin{array}{c}\text { Above } \\
\text { average }\end{array}$ & $\begin{array}{c}\text { Relatively } \\
\text { richer }\end{array}$ & \\
\hline $\begin{array}{l}\text { Not having } \\
\text { toilet }\end{array}$ & 27 & 15 & 24 & 11 & 77 \\
\hline Having & $(100)$ & $(75)$ & $(68.6)$ & $(40.7)$ & $(70.6)$ \\
toilet & 0 & 5 & 11 & 16 & 32 \\
\hline Total & $(0.0)$ & $(25)$ & $(31.4)$ & $(59.3)$ & $(29.4)$ \\
& 27 & 20 & 35 & 27 & 109 \\
& $(100)$ & $(100)$ & $(100)$ & $(100)$ & $(100)$ \\
\hline
\end{tabular}

Source: Compiled from primary data.

Note: Figures in the parentheses indicate percentage of households within the category

The cross tabulation of households as per monthly per capita income in the study area is presented in Table 10. Out of the four categories, 27 households are chronically poor, 20 are poor, 35 households are above average and 27 are relatively richer. The paper observes that not a single chronically poor household has a toilet. In case of poor category 75 percent households do not have own toilets. 68.6 percent of the 'above average income' category do not own toilets, whereas in the relatively richer category 59.3 percent households have owned a toilet. The Chi-square value of the test shows that it is 23.116 and the p-value is 0.000 . So the null hypothesis is rejected (Table13).

\subsubsection{Occupation category and toilet owning status}

Occupation is an important indicator of socio-economic status. The structure of occupation in India is heterogeneous and varies from person to person. A person having a good occupation earns a decent standard of living. On the contrary, there are some 
occupations which offer just the subsistence. Therefore, an obvious argument is that the occupation structure determines the toilet owning status. In the present study, data are taken from households belonging to the following four occupation categories as per the requirement of the present study: 0- if the household is a farmer or an agricultural labourer; 1, if low paid non-farm worker; 2, if high paid non- farm worker and industrial workers; and 3, if it is a service holder. It may be noted here that earning members of a family may be engaged in different occupations but the present paper has considered the occupation which contributes the highest proportion to the family income as the basis of categorising the household occupation.

Table 11 depicts the relationship between occupation and toilet owning status and it reveals whether occupation has a significant relationship on toilet owning or not. In the study are, there are 20 farming households, 48 are low paid non-farm workers, 31 families are in the category of high paid non-farm occupation and the remaining 10 families belong to the service holders category. Only one of the farming households, i.e. just 5 percent of the total $20 \mathrm{HHs}$ owns a toilet. Out of the 48 low paid non-farm households, 40 households (i.e. 83.3 percent) don't own toilets. In case of high paid nonfarm households 15 out of 31, i.e. 48.4 percent families own a toilet. However, under service holder category, out of ten families, 8 families ( 80 percent) own a toilet.

The Chi-square statistic is 27.23 and its p-value is 0.00 i.e. it is significant at $1 \%$ level of significance and the null hypothesis is rejected (Table 13). Therefore, toilet owning status is not independent of the household occupation.

Table 11: Occupation and Toilet Owning Status

\begin{tabular}{|r|c|c|c|c|c|}
\hline \multirow{2}{*}{$\begin{array}{c}\text { Toilet Owning } \\
\text { Status }\end{array}$} & \multicolumn{4}{|c|}{ Occupation Category } & \multirow{2}{*}{ Total } \\
\cline { 2 - 6 } & $\begin{array}{c}\text { Agricultural } \\
\text { Worker }\end{array}$ & $\begin{array}{c}\text { Low paid } \\
\text { non-farm } \\
\text { worker }\end{array}$ & $\begin{array}{c}\text { High paid } \\
\text { non-farm } \\
\text { worker }\end{array}$ & $\begin{array}{c}\text { Service } \\
\text { holder }\end{array}$ & \\
\hline Not having toilet & 19 & 40 & 16 & 2 & 77 \\
\cline { 2 - 6 } & $(95)$ & $(83.3)$ & $(51.6)$ & $(20)$ & $(70.6)$ \\
\hline Having toilet & 1 & 8 & 15 & 8 & 32 \\
\cline { 2 - 6 } & $(5)$ & $(16.7)$ & $(48.40$ & $(80)$ & $(29.4)$ \\
\hline Total & 20 & 48 & 31 & 10 & 109 \\
\cline { 2 - 6 } & $(100)$ & $(100)$ & $(100)$ & $(100)$ & $(100)$ \\
\hline
\end{tabular}

Note: Figures in the parentheses are the percent in column total. Source: Compiled from Primary Data 


\subsubsection{Education and toilet owning status}

Education is an important indicator of social status. A person having a good educational background means he or she earns a decent income for his livelihood. Apart from this, education makes people conscious and generates better awareness. It also fosters self-esteem. So, it is quite expected that education is an important determinant of the toilet owning status.

Table 12 depicts the relationship between education and toilet owning status of the sample households. The average years of schooling of adult members of the household (AE) is taken as the indicator of education. For the sake of comparison, education has been subdivided into two broad categories: less than 5 years of schooling and greater than or equal to 5 years of schooling. This categorization has been done on the basis of the quartile score. The study observes, the first quarter of the household has $\mathrm{AE}$ of 5 years. The 'less than 5 years of schooling' category consists of 24 households out of which 21 families do not have toilet. Likewise the second category consists of 85 households- out of which 29 families have own toilet. The chi-square test shows that the toilet owning status is not independent of the level of education. (Table 13).

Table 12: Education and Toilet Owning Status

\begin{tabular}{|l|c|c|c|}
\hline \multirow{2}{*}{ Toilet Owning Status } & \multicolumn{2}{|c|}{ EDUD } & \multirow{2}{*}{ Total } \\
\cline { 2 - 4 } & $\begin{array}{l}\text { 'AE below five years' } \\
\text { households }\end{array}$ & $\begin{array}{c}\text { 'AE at least five years' } \\
\text { households }\end{array}$ & \\
\hline Not having toilet & 21 & 56 & 77 \\
\cline { 2 - 4 } & $(87.5)$ & $(65.9)$ & $(70.6)$ \\
\hline Having toilet & 3 & 29 & 32 \\
\cline { 2 - 4 } & $(12.5)$ & $(34.1)$ & $(29.4)$ \\
\hline Total & 24 & 85 & 109 \\
\cline { 2 - 4 } & $(100)$ & $(100)$ & $(100)$ \\
\hline
\end{tabular}

Note: Figures in the parentheses indicates per cent within the category (refer column-wise)

Source: Compiled from primary data

\subsubsection{Chi-square test}

The summary of the chi-square tests is presented in Table 13. All the four null hypotheses are rejected as analysed previously. 'Toilet owning status' of households is not independent of their social category, income, occupation and education.

\subsubsection{Probit model estimation}

Considering the binary characteristics of 'Toilet Owning Status', the present paper has attempted to estimate a Probit model. The Probit model assumes that the decision 
of the $\mathrm{i}^{\text {th }}$ family to build a toilet depends on an unobservable utility index $\mathrm{I}_{\mathrm{i}}$ also known as latent variable that is determined by one or more explanatory variables say monthly per capita household income (MPCI), Average Education, Occupation, Caste category, Subsidy for toilet construction, in such a way that the larger the value of the index $\mathrm{I}_{\mathrm{i}}$, the greater the probability of a household owning a toilet.

Table 13: Results from chi-square tests

\begin{tabular}{|l|c|c|c|c|}
\hline \multicolumn{1}{|c|}{ Hypothesis } & Chi-square value & df & p- value & Decision \\
\hline $\begin{array}{l}\text { Toilet owning status is independent of } \\
\text { caste category. }\end{array}$ & 14.006 & 2 & .001 & Rejected \\
\hline $\begin{array}{l}\text { Toilet owning status is independent } \\
\text { of income. }\end{array}$ & 23.116 & 3 & .000 & Rejected \\
\hline $\begin{array}{l}\text { Toilet owning status is independent of } \\
\text { occupation }\end{array}$ & 27.228 & 3 & .000 & Rejected \\
\hline $\begin{array}{l}\text { Toilet owning status is independent of } \\
\text { education. }\end{array}$ & 4.217 & 1 & .040 & Rejected \\
\hline
\end{tabular}

Source: SPSS results from primary data

We can express the model as follows: $\mathrm{SNT}_{\mathrm{i}}=\beta_{0}+\beta_{1} \mathrm{OD}+\beta_{2} \mathrm{SCD}+\beta_{3} \mathrm{OBCD}+\beta_{4} \mathrm{SUB}+\beta_{5} \mathrm{MPCI}+\beta_{6} \mathrm{AE}+\mathrm{u}_{\mathrm{i}}$ where $\mathrm{OD}=$ Occupation dummy, which is 1 for high earning occupations, 0 -otherwise. $\mathrm{SCD}=$ Dummy for Scheduled Caste, which is 1 for No, 0 -otherwise.

$\mathrm{OBCD}=$ Dummy for $\mathrm{OBC}$, which is 1 for No, 0 -otherwise.

$\mathrm{SUB}=$ Dummy for subsidy, which is 1 for yes, 0 -otherwise.

MPCI= Monthly per capita household income measured in Rupee term.

$\mathrm{AE}=$ average years of schooling of adult members of the household.

The results of the model estimation are detailed in Table 14. MPCI and AE are the two scale variables but all others are categorical variables. It is observed that, except for education (AE) all the other variables in the model have their expected theoretical signs. Caste and government subsidy are the significant determinants of household 'access to sanitation'. SCD, OBCD and OD are found to be positive and significant in the model. The interpretations of the Probit estimation are as follows: A change of the Scheduled Caste dummy from 0 to 1 changes probability that SNT takes 1 increases by 47.2 percent. Similarly a change of the $\mathrm{OBC}$ dummy from 0 to 1 increases probability that SNT takes 1 by 41.1 percent, and government subsidy for latrine increases it by 48.8 percent. It may be noted that 'not belong to' $\mathrm{SC} / \mathrm{OBC}$ is considered as 1 . Although the coefficient of Occupation dummy is not significant at 5 percent level, it is significant at 
10 percent level. When households are engaged in high earning occupations, the probability of 'owning a toilet' increases by 28.5 percent. The chi-square statistic for the estimated Probit model is 198.18 which is significant at one percent level. It is clear from the empirical analysis that all determinants taken into consideration have more or less their usual signs towards the toilet owning status.

Table 14: Probit Model Estimation

\begin{tabular}{|c|c|c|c|c|c|}
\hline Parameter & Estimate & Std. Error & $\mathbf{Z}$ & Sig. & Interpretation \\
\hline Intercept & -3.454 & .257 & -13.428 & .000 & Significant \\
\hline OD & .285 & .162 & 1.755 & .079 & Not significant \\
\hline SCD & .472 & .191 & 2.470 & .014 & Significant \\
\hline OBCD & .411 & .177 & 2.315 & .021 & Significant \\
\hline SUB & .488 & .170 & 2.868 & .004 & Significant \\
\hline MPCI & .000 & .000 & 1.491 & .136 & Not significant \\
\hline AE & -.006 & .032 & -.192 & .848 & Not significant \\
\hline
\end{tabular}

*The coefficient is not significant at 5 percent level but it is significant at 10 percent level. Source: Estimated from primary data by SPSS

\subsection{Summary and Conclusion}

The study has also attempted to analyse the status of rural sanitary system and examine the various factors which are responsible for toilet use. In some of the previous studies, lack of awareness and behavioural aspect of the society were considered responsible for poor sanitary practices. The present paper examines the role of socioeconomic factors on sanitary status. On the basis of secondary data analysis, it is found that out of per capita NDP, rural literacy rate and regional dummy, only rural literacy rate (RLR) is found to have significant impact on toilet owning status. This shows that literate households use more toilets as compared to illiterate households. The study also reveals that, there is regional disparity among states on the basis of toilet owning status. KBK districts of Odisha are lagging far behind the coastal districts of the state. To be particular, the paper finds that there exists significant disparity between the Integrated Action Plan (IAP) districts and the non-IAP districts in PHHT.

All the null hypotheses which are taken into consideration in the study are rejected. The first hypothesis that, toilet owning status is independent of caste category has not been supported by data and the effect is observed to be significant ( $\mathrm{P}$ value $=.001)$. The second hypothesis, which states that toilet owning status is independent 
of income, is also rejected. Likewise the third and fourth hypotheses are rejected on the basis of their p-values. From the Probit analysis of primary data, the paper observes those caste category and government subsidies are the factors influencing the sanitary practices in the study area. The coefficient of occupation is also positive in the model but it not statistically significant at 5 percent. The p-value of occupation dummy is 0.079 . Households whose occupation is service and those who are in high paid non-farm work, their toilet owning status is better as compared to farmers and low paid non-farm workers.

Several studies have been carried out on sanitation to delineate the challenges. Some studies have also explored why people go for open defecation. However, disaggregated analysis on this important issue is quite limited. The present paper emphasises the major socio-economic determinants of poor sanitation of Odisha at district and household levels. There is ample scope for further research and exploration. The present study has tried to make some value addition by doing a micro level analysis. Some more relevant variables could be incorporated in the line of the ADB study (Sekhar et al., 2009) subject to data availability.

\section{Endnotes}

1. Efforts of the State Governments for promoting rural sanitation were supplemented by the centrally sponsored Rural Sanitation Programme (CSRP) till 1999. Subsequently there was the Total Sanitation Campaign (TSC) from 1999 to 2012. The TSC was a demand driven and people-centered sanitation program, which was modified as Nirmal Bharat Abhiyan from 2012. However, despite all these efforts only 40.6 percent of rural households in India has access to toilets (NSSO 2013). In order to make India open defecation free, on 2 October 2014, the Nirmal Bharat Abhiyan campaign is rechristened as Swachh Bharat Abhiyan (Clean India Mission) covering 4,041 statutory cities and towns. It is expected to cost over Rupees 620 billion (US\$9.2 billion). The government provides an incentive of Rs. 12,000 for each toilet constructed by a toilet-less household.

2. KBK stands for the formerly undivided Kalahandi-Bolangir-Koraput region. This includes Kalahandi, Nuapada, Bolangir, Subarnapur, Koraput, Nabarangapur, Rayagada and Malkangiri.

3. A Probit model measures the relationship between the strength of a stimulus and the proportion of cases exhibiting a certain response to the stimulus. It is useful for situations where you have a dichotomous output that is thought to be influenced or caused by levels of some independent variable(s) and is particularly well suited to experimental data. This procedure allows to estimate the strength of a stimulus required to induce a certain proportion of responses. 
4. BIMARU stands for Bihar(undivided), Madhya Pradesh(undivided), Rajasthan, and Uttar Pradesh (undivided). Very often the two eastern Indian states Odisha and Assam are also included in the same bracket.

\section{References}

Arnold, F. Parasuraman, S. Arokiasamy, P. \& Kothari, M. (2009). Nutrition in India. National Family Health Survey (NFHS-3), India, 2005-06. Mumbai: International Institute for Population Sciences; Calverton, Maryland, USA: ICF Macro.

Banda, K., Sarkar, R., Gopal, S., Govindarajan, J., Harijan, B. B., Jeyakumar, M. B., \& Thomas, V. A. (2007). Water handling, sanitation and defecation practices in rural southern India: A knowledge, attitudes and practices study. Transactions of the Royal Society of Tropical Medicine and Hygiene, 101(11), 1124-1130.

Barnard, S., Routray, P., Majorin, F., Peletz, R., Boisson, S. Sinha, A., \& Clase, Thomas. (2013). I mpact of Indian total sanitation campaign on latrine coverage and use: A cross sectional study in Orissa three years following programme implementation. PLoS One, 8(8): e71438, doi: 10.1371/journal.pone.0071438.

Bonu, S. \& Kim, H. (2009). Sanitation in India- progress, differentials, correlates, and challenges, South Asia Occasional Paper Series No. 2, Asian Development Bank. Retrieved from https://www.ircwash.org/sites/default/files/Bonu-2009-Sanitation.pdf

Coffey, D., Gupta, A., Hathi, P., Khurana, N., Spears, D., Srivastav, N., \& Vyas, S. (2014). Revealed preference for open defecation. Economic \& Political Weekly, 49(38), 43-55.

Fewtrell, L., Kaufmann, R. B., Kay, D., Enanoria, W., Haller, L. \& Colford, J. M. (2005). Water, sanitation, and hygiene interventions to reduce diarrhoea in less developed countries: A systematic review and meta-analysis. The Lancet Infectious Diseases, 5(1), 42-52.

Geruso, M., \& Spears, D. (2015). Neighborhood sanitation and infant mortality. Working Paper Series no. w21184. National Bureau of Economic Research. 
22 | PRAGATI: Journal of Indian Economy, Volume 4, Issue 1, January-June 2017

Kumar, A., \& Das, K. C. (2014). Drinking water and sanitation facility in India and its linkages with diarrhoea among children under five: Evidences from recent data. International Journal of Humanities and Social Science Invention, 3(4), 50-60.

National Sample Survey Office. (2016). Swachhta Status Report 2016. Ministry of Statistics and Programme Implementation, Government of India, New Delhi.

Patil, S. R., Arnold, B. F., Salvatore, A. L., Briceno, B., Ganguly, S., Colford Jr, J. M., \& Gertler, P. J. (2014). The effect of India's total sanitation campaign on defecation behaviors and child health in rural Madhya Pradesh: A cluster randomized controlled trial. PLoS Med, 11(8), e1001709. doi: 10.1371/journal.pmed.1001709

Routray, P., Schmidt, W. P., Boisson, S., Clasen, T., \& Jenkins, M. W. (2015). Sociocultural and behavioural factors constraining latrine adoption in rural coastal Odisha: An exploratory qualitative study. BMC Public Health, 15(1), doi: 10.1186/s12889-0152206-3.

World Health Organization. (2014). Preventing diarrhoea through better water, sanitation and hygiene: Exposures and impacts in low and middle-income countries. Geneva: WHO. 